\title{
Impact of COVID-19 on Redefining the Services of Educational Institutions using Ubiquitous Technology
}

\author{
Madhushree L. M. ${ }^{1}$, Bhuvana R. ${ }^{2}$, and P. S. Aithal ${ }^{3}$ \\ ${ }^{1}$ Research Scholar, College of Management \& Commerce, Srinivas University, Mangalore, \\ India \\ OrcidID: 0000-0001-9354-4151; Email: madhushreemraju@gmail.com \\ ${ }^{2}$ Research Scholar, College of Management \& Commerce, Srinivas University, Mangalore, \\ India \\ OrcidID: 0000-0001-9354-4152; Email: bhuvanareddy08@gmail.com \\ ${ }^{3}$ Professor, College of Management \& Commerce, Srinivas University, Mangalore, India \\ OrcidID: 0000-0002-4691-8736; E-mail: psaithal@gmail.com
}

Area/Section: Business Management.

Type of the Paper: Conceptual Analysis.

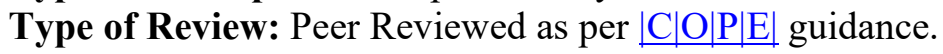

Indexed in: OpenAIRE.

DOI: http://doi.org/10.5281/zenodo.4216755

Google Scholar Citation: IJMTS.

\section{How to Cite this Paper:}

Madhushree L. M., Bhuvana R., and Aithal P. S. (2020). Impact of COVID-19 on Redefining the Services of Educational Institutions using Ubiquitous Technology. International Journal of Management, Technology, and Social Sciences (IJMTS), 5(2), 266-282. DOI: http://doi.org/10.5281/zenodo.4216755

International Journal of Management, Technology, and Social Sciences (IJMTS) A Refereed International Journal of Srinivas University, India.

(C) With Author.

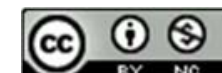

This work is licensed under a Creative Commons Attribution-Non-Commercial 4.0 International License subject to proper citation to the publication source of the work.

Disclaimer: The scholarly papers as reviewed and published by the Srinivas Publications (S.P.), India are the views and opinions of their respective authors and are not the views or opinions of the SP. The SP disclaims of any harm or loss caused due to the published content to any party.
\end{abstract}




\title{
Impact of COVID-19 on Redefining the Services of Educational Institutions using Ubiquitous Technology
}

\author{
Madhushree L. M' ${ }^{\mathbf{1}}$ Bhuvana R. ${ }^{2}$, and P. S. Aithal ${ }^{\mathbf{3}}$ \\ ${ }^{1}$ Research Scholar, College of Management \& Commerce, Srinivas University, Mangalore, \\ India \\ OrcidID: 0000-0001-9354-4151; Email: madhushreemraju@gmail.com \\ ${ }^{2}$ Research Scholar, College of Management \& Commerce, Srinivas University, Mangalore, \\ India \\ OrcidID: 0000-0001-9354-4152; Email: bhuvanareddy08@gmail.com \\ ${ }^{3}$ Professor, College of Management \& Commerce, Srinivas University, Mangalore, India \\ OrcidID: 0000-0002-4691-8736; E-mail: psaithal@gmail.com
}

\begin{abstract}
The COVID-19 affected each and every industry sector around the world. Most of the educational institutions of India as well as the world got affected very badly. It has forced worldwide lockdown and created an atrocious effect on student life. The COVID-19 affected all the sectors in $(\mathrm{T})$ the whole world, especially the education system around the world. In India, approximately 32 crore students stopped going to schools and colleges, and other training activities did not happen properly due to COVID-19. The outbreak of COVID19 and associated impact on student movement has advised us that change is inevitable in the education system. It has given a challenge and an opportunity to all the educational institutions to find a solution by determining suitable platforms and techniques for effective implementation of quality educational services, which has not been used before. Accordingly, the education sector has been fighting to continue its existence with a different approach by digitizing the challenges to wash the threat of the sickness. This paper also highlights some measures taken by Govt. of India to provide unified education in the country. Both the positive and negative impacts of COVID-19 are discussed and some productive suggestions are specified to bring out the educational activities back to normal during this bad situation. In this situation, every institution has adopted an online education model using information communication and computation technology (ICCT) due to COVID-19. This analysis is about how these technologies can help institutions continue online education and to know the student's capability to take-up online education. The major discussion is to know whether an institution can continue online education for students in future days or not.
\end{abstract}

Keywords: COVID-19, Higher education, Education technology, Students, Teachers, Parents.

\section{INTRODUCTION:}

In the first place, the COVID-19 virus is creating serious health issues leading to death. Many countries have decided to close the schools, colleges, and universities to avoid spreading of the Coronavirus. It sets the challenges between the closing of schools, allowing workers to remotely work and also to maintain the economy. Most of the people around the world are experiencing serious disturbances in the short term: Teaching occurs digitally and on an unapproved and incomparable scale. Student assessments are also available online, with many tests, errors and uncertainties. Mostly the evaluation and assessment processes have been simply cancelled due to the lack of their counterparts in the online mode. Importantly, these disruptions will not only be a short-term issue but may also have long-term consequences for the partners and are likely to increase inequalities. Lockdown imposed in almost all countries have decided to save citizens from the infection that has taken a toll for crushing the economy. The first work in the hands of governments is not only to save their public from infection by imposing lockdown and social distance but also to deal with the lockdown to save the economy. In any situation, everyone must think about how to solve pandemic situation and how to lead to positive 
thinking because it was a unpredicted situation. So, everyone should think positively and they must work hard. India's Government is no exemption to this. The Indian economy was going through a recession, and professionals said that the economy was heading toward depression even earlier the coronavirus. COVID-19 has distributed a significant blow to the economy [1], [2]. Itis going to be difficult to get out of such situation and depression until the lockdown is getting over. In the context of such a pandemic, the educational sector will collapse in all countries and many other industries. The Indian education system has been seriously impacted by the epidemic of the disease and by the social distancing steps taken to avoid the spread of the disease. The final act on the portion of the central government was to enforce a lockdown on the entire country [3].

\section{OBJECTIVE:}

The objective of this short communication is to examine the impact of COVID-19 on the higher education sector including

(1) To discuss the impact of the COVID-19 on educational institutions.

(2) To identify the challenges faced by the stakeholders due to COVID-19 in an educational institution.

(3) To understand the importance of educational technologies to be used to counter the impact of COVID-19.

(4) To list various educational technologies as underlying ICCT to be used for online teaching \& training.

(5) To suggest how educational institutions should adopt emerging ICCT technologies.

\section{IMPACT OF COVID-19 ON EDUCATIONAL INSTITUTIONS:}

Going to schools or colleges is a good public policy resource that develops skills and knowledge. While schools and colleges time means having fun and can also improve public aids and responsiveness, from an economic fact, the main point of presence in school and college is developing the child's ability and only in a short period in school or college see to this; even a comparatively short period of school will have values for the growth of skills. However, we can predict how much the disruption of COVID-19 will have a major effect on learning: not essentially as we are on a new planet, but we can use other experiments to assess the order of magnitude.

\subsection{Continuity of Learning Program}

In this circumstance of absence/sick leave or temporary school closing, students should be ensured continuous access to the quality of education. This can include

- Using online or e-learning methods

- Assigning reading and homework exercises

- Radio broadcast or television broadcast of academic content

- Assigning the teachers to follow up remotely with students on a daily or weekly basis

- Review/Develop accelerated education strategies

\subsection{Impact on education: families}

Probably some children were not usually sent to play due to COVID-19 so they are dissatisfied staying at home in the morning to night. The hope is that they should continue their schooling at home by using technology and hoping not to miss too much. Families are giving importance to education and are believed that to make a significant contribution to the development of the child and the current global expansion of home-schooling could be seen as helpful and possible to be effective. However, in general, this function seems to be additional work to school and college. So, while comprehensive home-schooling is definite it will create some inspiring moments, annoying moments, some enjoyable moments, and some disappointing moments. However, the main argument is that there are probably significant gaps between families and step into that they can help their children understand in learning by using technologies by staying home. As a result, this incident will increase the inequality of human capital growth in the affected partners [2]. 


\subsection{Professional support and preparation}

The unexpected start of the crisis has pushed many teachers into virtual classrooms, unprepared for the demands and goals of the modern world. The remote work has left them with inadequate and adapt to the virtual and distance learning, the virtual workspaces and courses, involved students in new and creative forms of learning. For some teachers, these difficulties reduced their own care responsibilities and lack of access to technology and services. In Quebec, for example, schools are mandated to have computers for teachers without them at home, but other costs, such as Internet access and telephone connections, are to be borne by the local school or college administration.

While almost all schools, tertiary institutions, and ministries of education have provided crash courses to the faculties to know about online content delivery, virtual classroom management, and technology use, and they have encouraged the change of teaching tools and learning materials to online platforms. In response to the ongoing pandemic, the smart universities offered an e-training course for teachers on how to handle online classrooms and use technology. Even though such measures to address immediate needs and the training shall be consistent with the professional standards, such attempts shall not challenge the quality of education and are systematically developed to complement virtual teaching in the long term.

The professional care and health measures are important so, while public meetings around the world are now being limited, some national and state governments must announce that school and college closures, which increases the question whether teachers have the right to refuse work on grounds that they are believed that it is unsafe. Even in cases where their facilities are not necessary for teachers that they should be instructed on the possible health and safety hazards of work and they should be dynamic in the development of effective policies to ensure a healthy and safe place of work, including access to sanitation supplies and training in precautionary measures.

The socio-emotional and psychological health impacts of COVID-19 and the pandemic response measures on staff, parents, and students - including anxiety, tension, and feelings of misunderstanding have not been broadly addressed, but they are important for organizational safety and health (OSH) as a part of protective equipment and social distance, to be taken into account when designing OSH strategies [1].

These social impacts are expected to be reduced and some countries are preparing to return to school, the teachers and education staff should talk about the risks of infection and issues related to discrimination in individuals' infectious threat. The additional burden of caring for families caused by coronavirus is credible to have an unpredictable effect on women employees due to the gendered division of family work. For many countries, especially in early childhood and primary education, and the teaching is a feminized profession and is consequently possible to be affected by this increased burden.

\subsection{Employment and working conditions}

Many schools and colleges have reduced the pay scales and remuneration for their teachers and other staff members for online teaching and work from home. Online and distance learning are the only possible solutions to continue the educational service during this pandemic time. The job security issues affecting the employees who were offering full time educational services to the students on campus. Massive online classes using internet-based technology have both merits and demerits. In several countries, teaching and training staff members of private education services are facing insecurity in their job due to the uncertainty of reopening the schools and colleges in time. The continuous closure of schools and colleges is also affecting the livelihood of other supporting services staff, including transport vendors, food suppliers, suppliers, etc. Throughout higher education, we can see the contract teachers and support workers, such as cleaners and catering staff, have faced dismissals problem with closing benefits to all international students. So, due to that, they have returned to their home countries, frequently in plans. In some schools and colleges, supply contract teachers have been terminated due to the government-mandated school closings, so in addition to the suspension of salary payments. 
The Union also influences the teachers with health problems, as outlined by the government, that they are left without the right to work and that teacher on maternity leave is permitted to leave early, even as contracts of those taking maternity leave are cancelled. Similar tendencies have been reported, with the alternate teachers and in some states, they are not receiving any salary payments during school and college lockdown and risking the loss of benefits. The crisis showing the weakness of fixed-term and non-unionized workforces and those without additional forms of shared representation. Supply and substitute teachers and other education support persons [2] [3].

\subsection{Lack of teacher training and resources}

Teachers from the so many countries are trying to determine ways to undergo teaching their students in this pandemic, it is difficult, where they can't give a physical interaction with students in this situation impossible. Once, period of community changes plays an important role in defining how teachers are effective in teaching the students during the pandemic. Teachers at the country's top private schools are tech-savvy: and the most have access to the Internet facility at home as well as the other digital infrastructure. Many of these things may have also investigated with e-learning facilities-like online suggestion of homework-before the crisis. This minority of educators must able to deliver notes to their students with adequate e-learning experience to ensure the continuation of schools and colleges in this pandemic. Unfortunately, this is not the case when it comes to the massive of teachers in the world that one in five primary school teaching posts is empty today due to technical skills because every organization needs a teacher with technology because the current education system is running on technology.

According to the World Bank, only half of India's teachers are currently teaching on any specified day because of sky-high rates for teachers. If an important is the number of teachers that they do not even teach if schools are open, it's tough to imagine a better result when schools are lockdown. Many of the teachers will excel in this new environment, but most teachers will need to upgrade not only with the technical skills but also in their teaching tools because most of the things will not be possible. However, we have seen a world without the classrooms, but an increasing number of teachers are unwilling to teach under such conditions, visualizing a world without teachers is difficult because how much ever technology changes the physical appearance of teachers is more important to teach students that what is society and how to behave in society is needed for every child and this will happen only when teachers and students meet face to face with the physical appearance.

\subsection{Government: Plans}

The govt. made so many changes in the education system due to COVID-19. And even the Indian Government has made a different education policy. So far, what we have learned from the official sources is an instruction that excludes schools from paying and hiking fees during the lockdown. Receiving a better picture of what they want to do whether this will benefit teachers and school and college owners around the country because everything is getting change but not happening positively, we must wait for everything to become normal. While some informal studies suggest that schools could open in the near future, which would mean that a large part of the academic year is missed [3] [4].

\section{CHALLENGES AND STRATEGIES USED BY EDUCATION INSTITUTIONS TO COUNTER COVID-19 :}

COVID-19 is a health crisis that is pandemic in nature. In addition, some countries have decided to close schools, universities, and colleges. This COVID-19 became a challenge for educational institutions to continue their service during the lockdown period. To counter this challenge, educational institutions have found online teaching as a remedy for their students. Many people around the world feel this short-term but severe disruption: Online teaching has emerged as a massive shock for both the productivity of the teacher and the students. Many appraisals were simply they have cancelled. Highly, these breaks are not only going to be a short-term issue but can also have many long-term effects. In such uncertain times, it is normal for people, including parents, to experience stress and anxiety. The closing of schools, colleges, and universities has disrupted the students ' learning flow 
and the existing way of imparting knowledge worldwide. In education, many unexpected issues have arisen which need to be tackled collaboratively. It is a challenge for educational institutes and teachers on how to reach students and ensure continuity of education through remote learning. In many countries around the world and India, schools and colleges are switching to the online mode. Being a new concept, however, many educational institutions have made a considerable number of efforts to implement this technology-based solution [5].

Table 1: The challenges faced by the educational stakeholders

\begin{tabular}{|c|c|c|}
\hline S. No & Stakeholders & Challenges \\
\hline 1 & Teachers & $\begin{array}{l}\text { 1. Some of the biggest difficulties that teachers face is how to keep } \\
\text { students onboard and how difficult to prevent disruptions from other } \\
\text { social networking sites during the learning time. } \\
\text { 2. The short-term transformation in teaching materials means } \\
\text { converting into digital format has been a challenge, as few teachers } \\
\text { have good computer and ICT skills. } \\
\text { 3. Teachers face problems related to Internet access. } \\
\text { 4. Students come from various social backgrounds and not every } \\
\text { student has access to a laptop or internet connection. It is not } \\
\text { possible for these students to take part in online courses. } \\
\text { 5. To preserve consistency in the teaching-learning process, the study } \\
\text { material is revised. } \\
\text { 6. Teachers started using Google classroom, Zoom, video call, and } \\
\text { other portals to contact students [6]. }\end{array}$ \\
\hline 2 & Students & $\begin{array}{l}\text { 1. Students face problems related to Internet access. } \\
\text { 2. The material divides - the disparities in essential services between } \\
\text { families required to support home learning. } \\
\text { 3. The digital divide - the differences in information and } \\
\text { communications infrastructure requirements and the know-how the } \\
\text { families have [7]. } \\
\text { 4. Skills and structures are fragmented - not all students are similarly } \\
\text { qualified to deal with home learning. } \\
\text { 5. Parental support deficit - certain parents are not well trained and are } \\
\text { unable to handle or cope with their children studying at home [8]. } \\
\text { 6. Split adaptations - the curriculum strategies used by schools to help } \\
\text { certain students learn are not adapted to home learning arrangements }\end{array}$ \\
\hline 3 & Parents & $\begin{array}{l}\text { 1. Most parents are hoping that this is a temporary occurrence that will } \\
\text { disappear with the lifting of the lockdown and re-opening of } \\
\text { schools. } \\
\text { 2. Some parents say online education is going to become a new } \\
\text { standard in the future days. } \\
\text { 3. Many schools do a few classes over video devices, but they are not } \\
\text { all open. Rural schools are deprived of educational services. } \\
\text { 4. Kids at the lowest level of society faced with a threat to their } \\
\text { livelihoods now face a strong vacuum, even as government } \\
\text { guidance tells schools to go online and accept homework as } \\
\text { classwork to mitigate disruption. } \\
\text { 5. Parents could not make their children to sit in front of computers for } \\
\text { online classes [9]. } \\
\text { 6. The school has been closed for over a week now. The new session } \\
\text { was scheduled to start the next month, but with the lockdown, they } \\
\text { are at home now and do not have their new books [10]. Under such } \\
\text { a case, it is difficult to form a routine. Online classes are important } \\
\text { to minimize disruption for high school and college students, but the } \\
\text { issue is that our educational institutions have the capacity to }\end{array}$ \\
\hline
\end{tabular}




\begin{tabular}{|l|l|}
\hline & $\begin{array}{l}\text { implement them and those teachers have the bandwidth to teach } \\
\text { through video apps. Others, however, see promising effects after a } \\
\text { long break [11] [12]. Coronavirus has changed life for all of us, } \\
\text { including our school system and children [7]. }\end{array}$ \\
\hline
\end{tabular}

\section{IMPORTANCE OF EDUCATIONAL TECHNOLOGIES TO BE USED TO COUNTER THE IMPACT OF COVID-19:}

\subsection{Importance of Technology :}

(1) Students demand: Students have more attraction on use of technology even when they are outside the classroom. Students want to be more competitive, and now technical learning has become a part of their lifestyle.

(2) New teachers are demanding: The use of technology has been implemented more in postsecondary teaching and in the other specialized work. The technology is considered as a prerequisite for the training media for new teachers [13].

(3) Students are technical instinctive: The Students know they are showing more interest about technology. It became the best way they learn because it is a significant part of their daily lives.

(4) Students should learn on their own: from years of experience that students are learning at their own pace but every now and then the conventional classroom makes it difficult to do so and frees the teacher to assist students with the adoption of technology at a more one-on-one basis in educational institution [14].

(5) There are no barriers for technology: Getting access to new technology and learning beyond the book technology provides students with various forms of learning.

(6) Technology can strengthen the teacher-student relationships: When teachers integrate technology efficiently into the subject areas, teachers advance in analyst, technical content, and coach positions. The technology helps and improve the meaning and fun in teaching and learning. In addition, the students can work with software solutions in collaboration with their own classmates.

(7) Multiple learning resources: The laptops, tablets, and other types of technology hold several tools for the non-book teacher. Not only to keep students interested in exciting new features and in the applications, they also have other forms of teaching significant learners.

(8) Technology keeps students engaged This generation's students are called technology learners. They learn the best and developed more social, and with confidence, technology allows them to do so. Children frequently struggle to remain on track or engaged, and they will better stay attentive and learn faster with the tools to support the teacher [15].

(9) To be competitive beyond the primary and secondary education, technology is needed: Whether we like it or not, the technology is a crucial component to learning. The children are better at technology-supported learning because it simplifies the learning process. It's an important part of any industry and there's no way around it.

(10) Students learning interest: The present generation students like the technology because they will get the information quickly according to their need so that it creates more interest in studies [16].

Table 2 depicts historical development of various technologies and their generations along with their characteristics.

Table 2: Technology Generations and their characteristics [17][18]

\begin{tabular}{|l|l|l|l|l|}
\hline $\begin{array}{l}\text { S. } \\
\text { No. }\end{array}$ & Generations & Technology & Characteristics & Era \\
\hline 1 & $\begin{array}{l}\text { First } \\
\text { Generation }\end{array}$ & $\begin{array}{l}\text { Mechanization } \\
\text { Technology }\end{array}$ & $\begin{array}{l}\text { Tools, Weapons, \& Printing. } \\
\text { (knowledge Era) }\end{array}$ & $\begin{array}{l}4,000-2,800 \\
\text { BC }\end{array}$ \\
\hline 2 & $\begin{array}{l}\text { Second } \\
\text { Generation }\end{array}$ & $\begin{array}{l}\text { Steam Engine } \\
\text { Technology }\end{array}$ & $\begin{array}{l}\text { Industrial Revolution } \\
\text { (Industrial era) }\end{array}$ & $\begin{array}{l}\text { The } \\
18 \text { th Century }\end{array}$ \\
\hline 3 & $\begin{array}{l}\text { Third } \\
\text { Generation }\end{array}$ & $\begin{array}{l}\text { Electricity } \\
\text { Technology }\end{array}$ & Power generation \& Usage & $\begin{array}{l}\text { The } \\
19 \text { th Century }\end{array}$ \\
\hline
\end{tabular}

Madhushree L.M., et al, (2020); www.srinivaspublication.com 


\begin{tabular}{|l|l|l|l|l|}
\hline 4 & $\begin{array}{l}\text { Fourth } \\
\text { Generation }\end{array}$ & $\begin{array}{l}\text { Automobile } \\
\text { Technology }\end{array}$ & $\begin{array}{l}\text { Long distance commuting \& } \\
\text { Transportation }\end{array}$ & $\begin{array}{l}\text { The } \\
\text { 20th Century }\end{array}$ \\
\hline 5 & $\begin{array}{l}\text { Fifth } \\
\text { Generation }\end{array}$ & $\begin{array}{l}\text { Airplane and space } \\
\text { Technology }\end{array}$ & $\begin{array}{l}\text { International Travel \& } \\
\text { Transportation }\end{array}$ & $\begin{array}{l}\text { The } \\
\text { 20th Century }\end{array}$ \\
\hline 6 & $\begin{array}{l}\text { Sixth } \\
\text { Generation }\end{array}$ & $\begin{array}{l}\text { Telephone } \\
\text { Technology }\end{array}$ & Distance communication & $\begin{array}{l}\text { The } \\
\text { 20th Century }\end{array}$ \\
\hline 7 & $\begin{array}{l}\text { Seventh } \\
\text { Generation }\end{array}$ & $\begin{array}{l}\text { Television } \\
\text { Technology }\end{array}$ & Video communication & $\begin{array}{l}\text { The } \\
\text { 20th Century }\end{array}$ \\
\hline 8 & $\begin{array}{l}\text { Eight } \\
\text { Generation }\end{array}$ & $\begin{array}{l}\text { Computer } \\
\text { Technology }\end{array}$ & Data Processing & $\begin{array}{l}\text { The } \\
\text { 20th Century }\end{array}$ \\
\hline 9 & $\begin{array}{l}\text { Ninth } \\
\text { Generation }\end{array}$ & $\begin{array}{l}\text { Internet } \\
\text { Technology }\end{array}$ & $\begin{array}{l}\text { Data and Information } \\
\text { Communication, E-business }\end{array}$ & $\begin{array}{l}\text { The } \\
\text { 20th Century }\end{array}$ \\
\hline 10 & $\begin{array}{l}\text { Tenth } \\
\text { Generation }\end{array}$ & $\begin{array}{l}\text { Mobile } \\
\text { Communication \& } \\
\text { Biotechnology }\end{array}$ & $\begin{array}{l}\text { Ubiquitous communication \& Bio- } \\
\text { engineering, Gene Therapy, }\end{array}$ & $\begin{array}{l}\text { The } \\
\text { 20th Century }\end{array}$ \\
\hline 11 & $\begin{array}{l}\text { Eleventh } \\
\text { Generation }\end{array}$ & $\begin{array}{l}\text { Information } \\
\text { Communication \& } \\
\text { Computation } \\
\text { (ICCT) underlying } \\
\text { Technologies }\end{array}$ & $\begin{array}{l}\text { Ubiquitous computing \& } \\
\text { Communication, and Total } \\
\text { Automation }\end{array}$ & $\begin{array}{l}\text { The } \\
21 \text { st Century }\end{array}$ \\
\hline 12 & $\begin{array}{l}\text { Twelfth } \\
\text { Generation }\end{array}$ & $\begin{array}{l}\text { Nanotechnology } \\
\text { Solutions to nutritious food, drinking } \\
\text { water, renewable energy, } \\
\text { Nanomedicine \& Therapy }\end{array}$ & $\begin{array}{l}\text { The } \\
21 \text { st Century }\end{array}$ \\
\hline
\end{tabular}

The eleventh and twelfth generations of technology are combinedly named Universal technologies and are $21^{\text {st }}$ century technologies. The universal technologies comprising ICCT underlying technologies and nanotechnology can provide complete product and service automation and are considered a boon to human beings if managed strategically [19][20].

\subsection{History of Educational Technology :}

The advents in technology generations provided many technological innovations in the education industry and made education services ubiquitous and more attractive to the teachers and learners. Table 3 lists major technological innovations that changed the classroom experience.

Table 3 : Top 20 technological innovations that changed the classroom experience

\begin{tabular}{|l|l|l|}
\hline $\begin{array}{c}\text { SI } \\
\text { No }\end{array}$ & $\begin{array}{l}\text { EdTech } \\
\text { Innovations }\end{array}$ & Characteristic \\
\hline 1 & The Epidiascope & $\begin{array}{l}\text { An epidiascope is a system used to project an image of both opaque and } \\
\text { crystal-clear images, primarily used for projecting images of book pages, } \\
\text { sketches, and mineral specimens, etc. An example of a large epidiascope } \\
\text { system was used in lectures and meetings to display mounted glass } \\
\text { slides [21]. }\end{array}$ \\
\hline 2 & Radio & $\begin{array}{l}\text { Radio channels are open and its job was to enrich the lives of people with } \\
\text { services and programs that inform, educate, and entertain. [22]. }\end{array}$ \\
\hline 3 & $\mathbf{1 6} \mathbf{~ m m ~ F i l m ~}$ & $\begin{array}{l}\text { Secondary schools have understood the dizzy heights of daily 16 mm film } \\
\text { projection on EdTech. The projectors remained stronger than the } \\
\text { epidiascope, so it was unessential to have a total blackout, but screens or } \\
\text { heavy drapes were still a must to go through the decreasing the facilities of } \\
\text { the school film library [23]. }\end{array}$ \\
\hline 4 & Schools TV & $\begin{array}{l}\text { The TVs and positions carefully matched the radio displays that had headed } \\
\text { them in size and design and were similarly turned around the } \\
\text { classroom [24]. }\end{array}$ \\
\hline
\end{tabular}




\begin{tabular}{|c|c|c|}
\hline 5 & $\begin{array}{l}\text { The OHP } \\
\text { (Overhead } \\
\text { Projector) }\end{array}$ & $\begin{array}{l}\text { The first real OHPs were created during World War II for air force usage in } \\
\text { planning and briefings and that they could have been trained with an OHP } \\
\text { or trained using one, and that fact without help demonstrates how much } \\
\text { effect they had in the classroom! [25]. }\end{array}$ \\
\hline 6 & The Whiteboard & $\begin{array}{l}\text { By replacing the blackboard with Whiteboard and got revolutionized } \\
\text { in teaching and learning. Suddenly clean, multi-colored plans could be } \\
\text { formed without projection, and the handwriting of the teacher became much } \\
\text { more understandable and less dusty in their clothing. }\end{array}$ \\
\hline 7 & $\begin{array}{l}8 \mathrm{~mm} \text { Loop } \\
\text { Projector }\end{array}$ & $\begin{array}{l}\text { Although } 16 \mathrm{~mm} \text { film was a rental market, it was planned for schools to buy } \\
8 \mathrm{~mm} \text { cine-loops in cassettes, and explicitly targeted learning and projector } \\
\text { screen that was light sufficient to move from room to space, if it was } \\
\text { bulky. Complete blackout was unnecessary although it helped darken the } \\
\text { room [26]. }\end{array}$ \\
\hline 8 & $\begin{array}{l}\text { Cassette- } \\
\text { recorder }\end{array}$ & $\begin{array}{l}\text { The unassuming audio cassette revolutionized the language teaching and } \\
\text { introducing both synchronicity and the ability to record and listen to the } \\
\text { previous radio-occupied vacuum and this is probably one of my (and my } \\
\text { back) favourable developments in the history of educational technology! }\end{array}$ \\
\hline 9 & Tape-slide & $\begin{array}{l}\text { Any clear catalyst took the idea of a cassette projector and the audio } \\
\text { recorder, with adding sound and power through the audiotape to the } \\
\text { projector [27]. }\end{array}$ \\
\hline 10 & The Videotape & $\begin{array}{l}\text { On unclassified reel-to-reel video recorders, but VHS video recorders } \\
\text { cleaned aside all earlier film innovations in the } 80 \text { 's. A genuinely ground- } \\
\text { breaking tool in the classroom that democratized sound-based moving } \\
\text { images. }\end{array}$ \\
\hline 11 & $\begin{array}{l}\text { PC } \\
\text { Microcomputer }\end{array}$ & $\begin{array}{l}\text { The initial microcomputers were interesting in having timers for recording } \\
\text { school broadcasts and slides. }\end{array}$ \\
\hline 12 & Video-projector & $\begin{array}{l}\text { The video-projector made it possible to share resources } 10 \text { and } 11 \text { with the } \\
\text { entire class now [28]. }\end{array}$ \\
\hline 13 & $\begin{array}{l}\text { Interactive } \\
\text { whiteboards } \\
\text { (IWBs) }\end{array}$ & $\begin{array}{l}\text { IWBs acquired a whiteboard, the knowledge of keyboard theory, and } \\
\text { combined it with a video projector to produce, which depends on the } \\
\text { pedagogical viewpoint. }\end{array}$ \\
\hline 14 & The Visualiser & $\begin{array}{l}\text { To end, somebody reinvented a reasonably low-cost tool digitally, with all } \\
\text { benefits of an image capture devices for displaying an object to a large } \\
\text { audience [26][27][28]. }\end{array}$ \\
\hline 15 & $\begin{array}{l}\text { The worldwide } \\
\text { Web }\end{array}$ & $\begin{array}{l}\text { The introduction of the web to classrooms, along with the class computer } \\
\text { and video projector, allowed for the first time truly global content sharing. A } \\
\text { fourth world wall window which could easily be used in any } \\
\text { classroom. What else should we wish for? }\end{array}$ \\
\hline 16 & Web 2.0 & $\begin{array}{l}\text { As people realized that creating online could be as simple as be consuming } \\
\text { it, a large number of really useful websites started to emerge and many } \\
\text { others permitted classrooms to produce sharing materials, as well as } \\
\text { accessing the plentiful resources the internet had to offer. }\end{array}$ \\
\hline 17 & $\begin{array}{l}\text { Virtual } \\
\text { Learning } \\
\text { Environments }\end{array}$ & $\begin{array}{l}\text { VLEs took a secure, and achieved resource allocation and meant exclusive } \\
\text { content sharing without teachers or students needing hundreds of usernames } \\
\text { and passwords to handle [29][30]. }\end{array}$ \\
\hline 18 & $\begin{array}{l}\text { Learning } \\
\text { Platforms }\end{array}$ & $\begin{array}{l}\text { Learning platforms on steroids, as long as patented sharing of content PLUS } \\
\text { student homework allocation and learning tools will become a best friend } \\
\text { of teachers very easily if used correctly! [31]-[35]. }\end{array}$ \\
\hline 19 & $\begin{array}{l}\text { Mobile } \\
\text { Technology }\end{array}$ & $\begin{array}{l}\text { Mobile technology has a massive range of potentials within the classroom } \\
\text { and frequently allows each scholar to learn at their own speed, to some } \\
\text { degree that has been shown to be tremendously beneficial on the Learning } \\
\text { platform itself [40]-[43]. }\end{array}$ \\
\hline
\end{tabular}


$20 \quad$ Augmented Reality/Virtual Reality
$\mathrm{AR}$ and VR, both unmoving in comparative infancy, carry a wow factor with them, and demonstrably useful learning advantages, but they still must be confirmed as a common tool for use in classrooms. As the maximum entry in the history of the timeline for educational technology, they may not have made an impact [13][32][34].

\subsection{Education Model for using Online Education technology}

Education technology is a known and integral factor of reforming and improving the educational system. The educational system started using online education technology to attract students and to create innovative learning [35]. Now, these tools are a common feature in the classroom, how can technology's combination in education be extended to best benefit students? How can educators integrate modern technologies to improve education and assess what proves effective? What future revolutions can be expected in educational technology to attract students by adopting an online education system? To answer these questions, a model for the online education cycle is shown in figure 1.

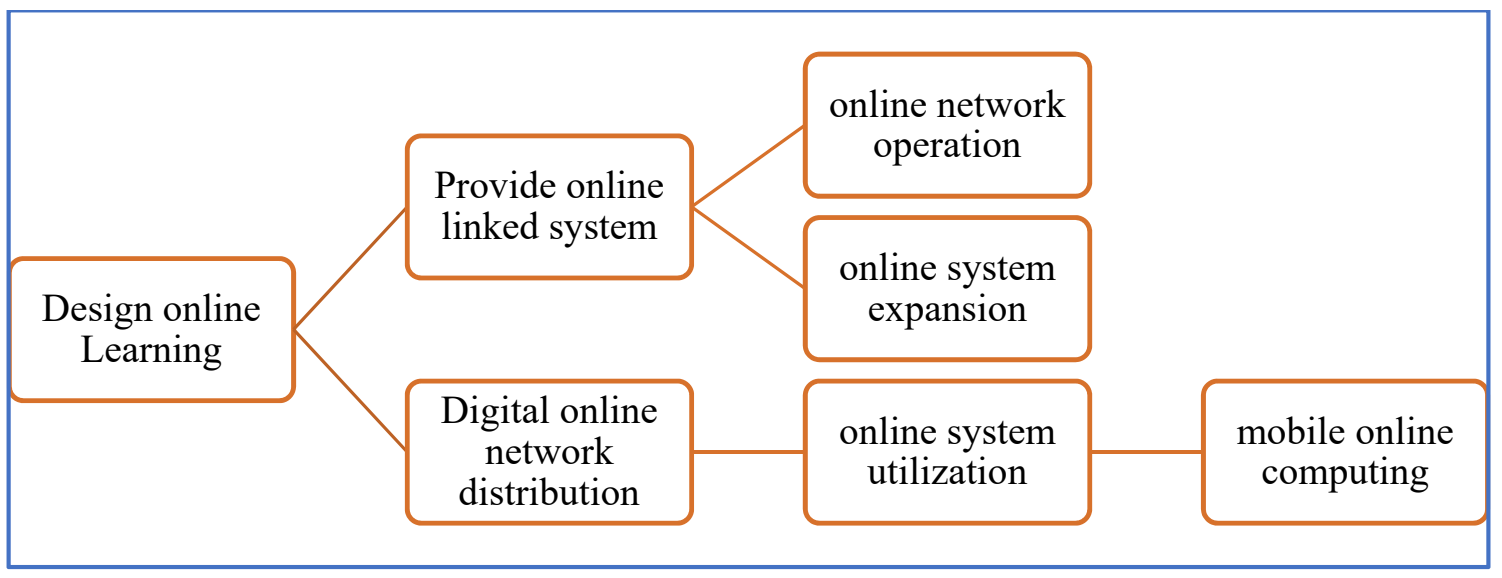

Fig. 1: Block diagrammatic representation of Online education Cycle

(1) Online learning design: Online learning design is a system, which supports the learning experience. This refers to conscious decisions on what to say, where, where, and how.... The idea of "Online Learning Design" has gained traction in the educational space recently, mainly through conference discussions, webinars, eBooks, and more [36].

(2) Providing a connected online system: A learning management system (LMS) is one type of online learning platform. Such as teaching foreign languages or an online college course, an LMS supporting of all skills needed to build E-Learning and create educational media.

(3) The distribution of distributed media networks: Internet (also stated as content transfer, online distribution, or the electronic software distribution (ESD), between others) is used to delivery or distribution of digital media content such as audio, video, e-books, video games, and other software [37].

(4) The growth of the online system: Online education growth focuses, in particular, on growing social disparity regarding access to higher education institutions. It is a versatile instructional delivery system that incorporates every form of learning that occurs over the Internet.

(5) The usage of the online system: Online (OL) is an Internet-based education system. Among other words, it is frequently mentioned as "e-learning." Online learning, though, is just one form of "distance learning" [30][31].

(6) Mobile online computing: Mobile learning is Internet education or networking education with personal mobile devices, such as tablets and smartphones, to access-learning material through mobile apps, social networks, and online educational hubs. It is a multipurpose facility and allows students to access information anywhere related to their education [25]. 


\section{VARIOUS EDUCATIONAL TECHNOLOGIES UNDER ICCT TO BE USED FOR ONLINE} TEACHING \& TRAINING:

\subsection{Information Communication and Computation Technology}

Information Communication and Computation Technology (ICCT) is viewed as universal technology with many underlying emerging technologies within it (Table 4). ICCT is grown and spread its roots to all industries [17][18].

Table 4: Application of various Underlying Information Communication and Computation Technologies

\begin{tabular}{|c|c|c|}
\hline $\begin{array}{l}\text { S. } \\
\text { No }\end{array}$ & $\begin{array}{l}\text { ICCT Underlying } \\
\text { Technologies }\end{array}$ & Applications in the education sector \\
\hline \multirow[t]{3}{*}{1} & \multirow{3}{*}{$\begin{array}{l}\text { Artificial } \\
\text { Intelligence (AI), } \\
\text { Machine Learning, } \\
\text { \& Robotics }\end{array}$} & $\begin{array}{l}\text { AI has been applied to education primarily in some tools that help to } \\
\text { develop skills and testing systems and it also can drive efficiency, } \\
\text { personalization, and streamline admin tasks to teachers [38]-[42]. }\end{array}$ \\
\hline & & $\begin{array}{l}\text { Machine learning is a subset of AI that helps computers or } \\
\text { Teaching Machines learn from all previous ones and make wise decisions } \\
\text { [43]. In the field of education, teachers can save Time in their non-school } \\
\text { activities by using machine learning [44]-[45]. }\end{array}$ \\
\hline & & $\begin{array}{l}\text { Robotics and simulators will change the way students learn and eventually } \\
\text { contribute to a more knowledgeable and well-adjusted student. Robotics- } \\
\text { Robots may be used to carry students to the classroom who may not be } \\
\text { able to join otherwise [46] [47] [48]. }\end{array}$ \\
\hline 2 & $\begin{array}{l}\text { Big data and } \\
\text { Business analytics }\end{array}$ & $\begin{array}{l}\text { Data analysis consolidates information to provide a broad view of trends } \\
\text { and patterns for higher education leadership teams that can be used to } \\
\text { analyse and streamline processes, build efficiencies, and enhance the } \\
\text { overall student experience [49], [50]. }\end{array}$ \\
\hline 3 & $\begin{array}{l}\text { Blockchain } \\
\text { technology }\end{array}$ & $\begin{array}{l}\text { The most promising use of blockchain in higher education is the } \\
\text { transformation of the "recording" of degrees, qualifications and diplomas, } \\
\text { the development of digital certification, and under the control of the } \\
\text { learner, without the need for an intermediary to validate them [17], [18], } \\
\text { [68], [69], [70]. }\end{array}$ \\
\hline 4 & Cloud technology & $\begin{array}{l}\text { Cloud computing provides students with access to assignments and also } \\
\text { allows teachers to immediately upload learning materials and } \\
\text { administrators to collaborate and save money on data storage anywhere } \\
\text { the internet is connected [51] [52] [53]. }\end{array}$ \\
\hline 5 & $\begin{array}{l}\text { Cyber Security } \\
\text { technology }\end{array}$ & $\begin{array}{l}\text { Educational institutions retain a large amount of confidential data, ranging } \\
\text { from study to test records to personal information for students. While } \\
\text { cyber security in the financial sector receives considerable attention, and } \\
\text { recent guidance also highlights the vulnerability of the education sector. } \\
\text { [17]. }\end{array}$ \\
\hline 6 & $\begin{array}{l}\text { 3D Printing } \\
\text { technology }\end{array}$ & $\begin{array}{l}\text { 3D printing enables educators to design rich learning environments with } \\
\text { deep theoretical structures that introduce learning from computer screens } \\
\text { to students' hands. Digital 3D environments come to life with 3D printers } \\
\text { that can facilitate sharing, teamwork, planning, design, and dreaming } \\
\text { about difficult or complex ideas [54]-[58]. }\end{array}$ \\
\hline 7 & Digital Marketing & $\begin{array}{l}\text { Digital marketing had a significant impact not only on the marketing of } \\
\text { higher education but also on higher education as a whole. Many academic }\end{array}$ \\
\hline
\end{tabular}




\begin{tabular}{|l|l|l|}
\hline & & $\begin{array}{l}\text { institutions around the world are now using digital marketing tools not } \\
\text { only to communicate and engage their future audiences but also to teach } \\
\text { and learn [59] [60] [61]. }\end{array}$ \\
\hline 8 & $\begin{array}{l}\text { Internet of things } \\
\text { (IoT) }\end{array}$ & $\begin{array}{l}\text { IoT in schools means a better-connected, more interactive future for } \\
\text { education. IoT devices give students greater access to everything from } \\
\text { learning materials to communication networks and allow teachers to } \\
\text { assess student progress in real-time [62] [63]. }\end{array}$ \\
\hline 9 & $\begin{array}{l}\text { Quantum } \\
\text { Computing }\end{array}$ & $\begin{array}{l}\text { One of the best sources for initial education on the basics of Quantum } \\
\text { Computing is Quantum Computing for the Determined by Michael } \\
\text { Nielsen. This consists of 22 short videos that discuss the Basics, } \\
\text { Superdense Coding, Quantum Teleportation, and The Postulates of } \\
\text { Quantum Mechanics [17] [18]. }\end{array}$ \\
\hline 10 & $\begin{array}{l}\text { Information } \\
\text { Storage } \\
\text { Technology }\end{array}$ & $\begin{array}{l}\text { Information technology in education has made it possible for students to } \\
\text { continue learning, wherever they might be. Teachers and professors can } \\
\text { give assignments to students and can complete and submit them even } \\
\text { without entering the classroom physically so that learning can never stop } \\
\text { [14][16][17]. }\end{array}$ \\
\hline 11 & $\begin{array}{l}\text { Virtual Reality and } \\
\text { Augmented Reality }\end{array}$ & $\begin{array}{l}\text { By providing an immersive and interactive learning environment without } \\
\text { the use of textbooks, AR and VR technology empowers learners to explore } \\
\text { and learn at their own speed, stimulating learning and understanding and } \\
\text { improving essential retention [64]. }\end{array}$ \\
\hline 12 & $\begin{array}{l}\text { Ubiquitous } \\
\text { Technoation }\end{array}$ & $\begin{array}{l}\text { U-education technologies can be used to provide personalized services in } \\
\text { the context-aware of the U-learning environment. Ubiquitous computing } \\
\text { in Education, as defined by the teachers and students having access to } \\
\text { technology (computing devices, the internet, services) whenever they } \\
\text { need it [18]. }\end{array}$ \\
\hline
\end{tabular}

6.2 Teaching \& Training models under Ubiquitous Education Technology:

(1) Ubiquitous computing: Digital technology is continuously emerging and increasing its impact in every sector. It is obvious that this growth will bring the world's latest and exciting developments continuously. Another modern approach now emerging is the introduction of the mass media for the delivery of education.

(2) Adaptive learning: Adaptive learning is mainly based on the promise of adapting the learning systems to the individual styles of the students. The idea is that each individualized teaching approach will help students learn more easily, more effectively, and with better comprehension [64].

(3) E-learning: E-learning has given students innovative ways to access and understand many properties. This was an important innovation in the education sector to drive both in-house tertiary education and distance education to manage better.

(4) M-Learning: M-Learning has also deemed a type of e-Learning, and is claimed that mobileLearning is a new phase in the development of e-Learning and is within its borders. Compared to elearning, the advantages of m-learning include versatility, cost, scale, ease of use, and timely implementation. The devices used included PDAs, cell phones, laptops, and tablet PCs [65].

The devices/components used for Ubiquitous Education Technology include :

(1) Microprocessor based Electronic Systems with associated memories are used to process and store information related to the teaching and learning process. The sensor senses their presence when a student enters, and it will start communicating information to the students.

(2) Ubiquitous Learning Environment (ULE) Server Module with associated Server, Educational Tactic Unit and Database: ULE Server be able to have network resources and analyses student answers to short quiz questions and proceeds more information or information in a changed form when needed; Database - stores all data on 'objects/devices, users, and connections that occur [66]. 
(3) Wireless Technology: This would take the system of Bluetooth and Wi-Fi. Bluetooth can function at poor signal bandwidth, requires less power and it spans a relatively short distance. Wi-Fi has low power consumption and communication abilities with multiple users and highly useful for handheld devices. Created on IEEE specification 802.11, Wi-Fi has a range and speed that exceeds that of Bluetooth. It is well-matched with any access point brand and client hardware created to the Wi-Fi standard.

(4) Sensors- Sensors are to be used to monitor any external changes in the signal level and learner's environment. These are mounted in-line with the learning device and are used to identify students' presence in the learning process. The sensors are mainly used to monitor the learner's movement and changes in light intensity to detect changes in the learning environment [67].

\section{PREDICTIONS \& SUGGESTIONS FOR FUTURE OF HIGHER EDUCATION POST COVID-19:}

Based on the above analysis it can be predicted that the education delivery model in higher education level will change post-COVID-19 which may include:

(1) Blended learning - a reality: The campus-based classroom teaching is expected to be partially replaced by online classes. In this way, students will be expected to attend classes physically for fewer days and will be able to study at their own pace. It will also allow them to focus more time to assimilate knowledge [30].

(2) Teaching techniques will be qualitatively different: All teachers will be trained for using online teaching techniques. It would go a long way to ensure that they are familiar with technology and able to transition seamlessly between online and offline learning methods. Above all, the teachers should feel encouraged inherently to give more effective lectures than ever before.

(3) The use of Artificial Intelligence (AI) will help personalize the learning experience for Individuals: Eventually, educators will have to abandon the 'one-size-fits-all' approach that is often practiced in conventional classrooms and use technology to provide a learning environment that is specifically tailored to students learning needs. The integrated approach to learning, in effect, would benefit all types of students because they will have the opportunity to interact with various forms of content, such as video, audio, presentations, thereby, and their ability to personalize learning [38][39].

(4) The role of teachers will need to be redefined: With information readily accessible just a click away, the role of the 'knowledge-giver' teacher will slowly change to that of the 'facilitators in the growth of learners and help them become lifelong learners.

(5) Technology should be used effectively to reduce the time spent by teachers on activities such as paper-setting, assessment, and grading: This will allow teachers to concentrate fully on teaching and developing courses.

(6) Interactivity and participation in the physical classroom would have to be incorporated into the online learning systems to keep students engaged: Physical classrooms provide a high degree of contact with teachers and students. Alternately, educators would have to put many developments into their e-learning models and platforms to add the dimension of interactivity and collaboration [9] [10].

(7) The concepts of social distancing will have to be incorporated: If colleges, coaching centers, and other educational institutions open up after COVID-19 challenges, new regulations on social distancing will inevitably change the current models of classroom education. Schools may go working in shifts, classrooms will obey strict sanitization procedures, and social barriers will become the rule for all activities.

It should also be noted that, in the context of social distance, self-isolation, and online studies in the current quarantine era, it is only natural that students face unprecedented levels of anxiety. It may not be easy for them to hang out with their friends, peers, and classmates as they used to, and not be able to spend their energy on sports. All educators should take responsibility for equipping them with appropriate coping mechanisms and help each other to build and strengthen their relationships with supportive adults, including their teachers [11] [12].

\section{CONCLUSION:}

The COVID-19 has hit the comfort levels of everybody in the world, including the schools and colleges, which usually have a place of real-life of growing children and youths, physical contact/communication, have been stooped. Millions of students around the world continue to study at home using online 
education technology. It remains a big question on how educators and other stakeholders of the sector, as a whole, can cope with the current online learning-at-home model as a true and acceptable learning model. In India, technical approaches to this problem seem currently limited to leading urban-centric institutes. However, if the lockdown continues, there is a real and urgent need to modernize the technologies that can help Indians learn remotely in the world. So mainly one should understand that predictions may not be a solution every time but one should be ready for everything to accept and to make changes by adopting technology and continuing the education system for the progress in society.

\section{REFERENCES:}

[1] Keerthan Raj, \& Aithal, P. S. (May 2020). The Post COVID-19 World: Efforts Needed to Build Back a More Resilient Society. International Journal of Case Studies in Business, IT, and Education (IJCSBE), 4(1), 88-93. DOI: http://doi.org/10.5281/zenodo.3783563.

[2] Gururaj Itagi, \& Aithal, P. S. (2020). A Study on the Future of World Leader's Behavior towards Global Health after COVID-19. International Journal of Case Studies in Business, IT, and Education (IJCSBE) 4(1), 127-135. DOI: http://doi.org/10.5281/zenodo.3839765.

[3] Jadhav V. R., Bagul T. D., \& Aswale S. R. (2020). COVID-19 era: students' role to look at problems in the education system during lockdown issues in Maharashtra, India. International Journal of Research and Review, 7(5), 328-331.

[4] Amit Kumar Arora, R., \& Srinivasan. (2020.). The impact of Pandemic COVID-19 on the Teaching - Learning Process: A Study of Higher Education Teachers. Prabandhan: Indian journal of management, 13(4), 214-222.

[5] Alqurashi, E. (2018). Predicting student satisfaction and perceived learning with online learning environments. Journal of Distance Education, 40(1), 133-148.

[6] Lone, A. Z. (2017). Impact of online education in India. IJESC, 7(7), 13050- 13952.

[7] http://www.education.ie/en/Schools-Colleges/ Information/Information-Communications Technology-ICT-in-Schools/ Digital-Strategy- for-Schools/ Building-Towards-a-LearningSociety-ANational-Digital-Strategy-for-Schools- Consultative-Paper.pdf. . . Retrieved on 03/07/2020.

[8] Survey on Impact of COVID-19 education: https://docs.google.com/ forms/d/e/1FAIpQLSeTCGnwjC7ArrPPpEQ_dqg9L_1Dp YjdJ 0evnvBuOJKkjH25w/viewform?usp=sf_lin k. Retrieved on 02/07/2020.

[9] Sprague, D., Maddux, C., Ferdig, R., \& Albion, P. (2007). Editorial: Online education: Issues and research questions. Journal of Technology and Teacher Education, 15(2), 157-166.

[10] www.iauaiu.net/pdf/covid19 and he resour ces. The impact of COVID-19 on higher education worldwide........Retrieved on 03/07/2020.

[11] http://www.educationinsider.net/detail news.php?id=1326 ........Retrieved on 03/07/2020.

[12] Piopiunik, M., Schwerdt, G., Simon, L., \& Woessman, L. (2020). Skills, signals, and employability: An experimental investigation. European Economic Review, 48 (1), 41-55.

[13] https://thirdspacelearning.com/blog/history-of-educational-technology Retrieved on 05/07/2020.

[14] Madhushree L. M., Pradeep M. D., \& Aithal, P. S. (2019). Boosting Education through Mobile Technology in India - Study with reference to Generation Z. International Journal of Applied Engineering and Management Letters (IJAEML), 3(2), 96105. DOI: http://doi.org/10.5281/3597588.

[15] Kavanagh, S., Luxton-Reilly, A., Wuensche, B., \& Plimmer, B. (2017). A systematic review of Virtual Reality in education. Themes in Science and Technology Education, 10(2), 85-119. 
[16] Aithal P. S., \& Suresh Kumar P. M. (2018). Approaches to Confidence Building as a Primary Objective in Postgraduate Degree Programs. International Journal of Applied Engineering and Management Letters (IJAEML), 2(1), 64-71. DOI: http://dx.doi.org/10.5281/zenodo.1205185.

[17] Aithal, P. S., \& Madhushree, L. M. (2019). Information Communication \& Computation Technology (ICCT) as a Strategic Tool for Industry Sectors. International Journal of Applied Engineering and Management Letters (IJAEML) 3(2), 6580. DOI: http://doi.org/10.5281/zenodo.3549423.

[18] Aithal, P. S., \& Shubhrajyotsna Aithal. (2019). Management of ICCT underlying Technologies used for Digital Service Innovation. International Journal of Management, Technology, and Social Sciences (IJMTS), 4(2), 110-136. DOI: http://doi.org/10.5281/zenodo.3591139.

[19] Cruz, F. J. F., \& Díaz, M. J. F. (2016). Generation z's teachers and their digital skills. Comunicar. Media Education Research Journal, 24(1), 97-105.

[20] Clarke, S. (2009). New technologies, common sense and the paradoxical precautionary principle in Evaluating New Technologies. Springer, 3(1), 159-173. DOI https://doi.org/10.1007/978-90481-2229-5 11;

[21] Georgiev, T., Georgieva, E., \& Smrikarov, A. (2004). M-Learning - a New Stage of eLearning. International Conference on Computer Systems and Technologies, 1(1), 17-18.

[22] Gersten, R., \& Baker, S. (1998). Real world use of scientific concepts: Integrating situated cognition with explicit instruction. Exceptional Children, 65(1), 23-36.

[23] http://www.gsu.edu/ mstswh/courses/it7000/papers/situated.htm ......... Retrieved on 13/09/2020.

[24] Jones, Marlene, Winne, \& Philip H. (1992), Adaptive learning environments: Foundations and frontiers. Springer-Verlag Berlin Heidelberg, 85(1), 383-408. Doi: 10.1007/978-3-642-77512-3

[25] Paramythis, A., \& Loidl-Reisinger, S. (2004). Adaptive learning environments and e-learning standards. Electronic Journal of eLearning, 2(1), 181-194.

[26] Barton, L., \& Slee, R. (1999). Competition, selection, and inclusive education: Some observations. International Journal of Inclusive Education, 3(1), 3-12.

[27] Weiser, M. (1991). The computer for the twenty-first century. Scientific American, September, 1(1), 94-104.

[28] Weiser, M. (1993). Some computer science issues in ubiquitous computing. Communications of the ACM, 36(7), 74-83.

[29] Barnard, J. (1997). The worldwide Web and Higher Education: Promise of Virtual Universities and On-Line Libraries. Educational Technologies, 37(1), 30-35.

[30] Berge, Z. L. (1999). Interaction in Post-Secondary Web-Based Learning. Educational Technology, 38(1), 57- 61.

[31] Weick, K. (1989). Theory construction as disciplined imagination. Academy of Management Review, 14(4), 516-531.

[32] Warkentin, M., Sayeed, L., and Hightower, R. (1997). Virtual teams versus face-to-face teams: An exploratory study of a Web-based conference system. Decision Sciences, 28(4), 975-996.

[33] Tenkasi, R., \& Boland, R. Jr. (1996). Exploring knowledge diversity in knowledge intensive firms: A new role for information systems. Journal of Organizational Change Management, 9(1), 79-91.

[34] English, S., \& Yazdani, M. (1999). Computer-Supported Co-Operative Learning in A Virtual University. Journal of Computer Assisted Learning, 15(1), 2-13.

[35] Thomas, G. (1996) Education and Technology in The Third Wave. Oxford Review of Education, 12(3), 223-231. 
[36] Hopper, K. (1999) Mastering the Invisible Technologies in Education: Who are the Real Technology Prodigies Among College Teachers. Educational Technology, 1(1), 50-55.

[37] Khoshnevis, B. (2001) Experimental investigation of contour crafting using ceramic materials. Rapid Prototyping Journal, 7(1), $32-42$.

[38] Mellit, A., \& Kalogirou, S. A. (2008). Artificial intelligence techniques for photovoltaic applications: A review. Progress in Energy and Combustion Science, 34(5), 574-632. DOI: 10.1016/j.pecs.2008.01.001.

[39] Kalogirou, S. A. (2003). Artificial intelligence for the modeling and control of combustion processes: a review. Progress in Energy and Combustion Science, 29(6), 515-566. DOI: 10.1016/s0360-1285(03)00058-3.

[40] Cockburn, I., Henderson, R., \& Stern, S. (2018). The Impact of Artificial Intelligence on Innovation. National Bureau of Economic Research, 1-38. DOI: 10.3386/w24449.

[41] O'Leary, D. E. (2013). Artificial Intelligence and Big Data. IEEE Intelligent Systems, 28(2), 9699. DOI: $10.1109 / \mathrm{min} .2013 .39$.

[42] Rupali Kamble, \& Deepali Shah. (2018). Applications of Artificial Intelligence in human life. International Journal of Research - Granthaalayah, 6(6), 178-188. https://doi.org/10.5281/zenodo.1302459.

[43] Jiang, C., Zhang, H., Ren, Y., Han, Z., Chen, K.-C., \& Hanzo. L. (2017). Machine learning paradigms for next-generation wireless networks, IEEE Wireless Communications, 24(2), 98-105.

[44] Simeone, O. (2018). A brief introduction to machine learning for engineers. Foundations and Trends in Signal Processing, 12(4), 200-431.

[45] Brynjolfsson, E. and Mitchell, T. (2017). What can machine learning do? Workforce implications, Science, 358(6370), 1530-1534.

[46] Alexander Shkolnik, Michael Levashov, Ian, R., Manchester, \& Russ Tedrake. (2010). Bounding on Rough Terrain with the Little Dog Robot. The International Journal of Robotics Research, 1(1), 1-24. DOI: $10.1177 / 0278364910388315$.

[47] Ballantyne, G.H., and Moll, F. (2003). The da vinci telerobotic surgical system: The virtual operative field and telepresence surgery, Surg. Clin. North America., 86(6), 1293-1304.

[48] Huang, K., Yokoi, S., Kajit, K., Kaneko, H., Arai, N., Koyachi, \& Tanie, K. (2001). Planning walking patterns for a biped robot. IEEE Trans. Robot. Automation, 17(3), 280-289.

[49] Ifeyinwa Angela Ajah, \& Henry Friday Nweke. (2019). Big Data and Business Analytics: Trends, Platforms, Success Factors and Applications. MDPI, 3(1), 1-32. Doi: doi:10.3390/bdcc3020032.

[50] Dorota Jelonek. (2017). Big Data Analytics in the Management of Business. EDP Sciences, 1(1), 1-6. DOI: $10.1051 / \mathrm{matecconf} / 201712504021$

[51] Xu, X. (2013). Cloud manufacturing: A new paradigm for manufacturing businesses. Australian Journal of Multi-Disciplinary Engineering, 9(2), 105-116.

[52] Kodandaramaiah Keerthi, G. N. (2015). cloud IoT Based greenhouse Monitoring System|", Int. Journal of Engineering Research and Applications, 5(10), 35-41.

[53] Aithal, P. S., \& Priest Pai, T. (2017). Opportunity for Realizing Ideal Computing System using Cloud Computing Model. International Journal of Case Studies in Business, IT and Education (IJCSBE), 1(2), 60-71. DOI: http://dx.doi.org/10.5281/zenodo.1094995.

[54] Holzmann, P., Robert, J., Aqeel Breitenecker, V., Soomro, J. S., \& Erich. (2017). User entrepreneur business models in 3D printing. Journal of Manufacturing Technology Management, 28(1), 75-94. 
[55] Ze-Xian, L., Yen, T. C., Ray, M. R., Mattia, D., Metcalfe, I. S., \& Patterson. D. A. (2016). Perspective on 3D printing of separation membranes and comparison to related unconventional fabrication techniques. Journal of Membrane Science, 523(1), 596-613.

[56] Rajan, V., Sniderman, B., Baum. P. (2016). 3D opportunity for life: Additive manufacturing takes humanitarian action. Delight Insight, 1(19), 1-8.

[57] Keles, O., Blevins, C.W., Bowman, K. J. (2017). Effect of build orientation on the mechanical reliability of 3D printed ABS. Rapid Prototyping Journal, 23(2), 320-328.

[58] Low, Z., Chua, Y. T. Ray, B. M. Mattia, D., Metcalfe, I.S. Patterson, D. A. (2017). Perspective on $3 \mathrm{D}$ printing of separation membranes and comparison to related unconventional fabrication techniques. Journal of Membrane Science, 523(1), 596-613.

[59] Haikio, J., \& Koivumaki, T. (2016). Exploring the digital service innovation process through value creation. Journal of Innovation Management, 4(2), 96-124.

[60] Bertot, J. C., Estevez, E., \& Janowski, T. (2016). Digital public service innovation: Framework proposal. Proceedings of the 9th International Conference on Theory and Practice of Electronic Governance 1(1), 113-122

[61] Witlicki, Edward, H., Johnsen, Carsten, Hansen, Stinne W., Silverstein, Daniel W., Bottomley, Vincent J., Jeppesen, Jan O., Wong, Eric, W., Jensen, Lasse Flood, \& Amar, H. (2011). Molecular logic gates Using Surface-Enhanced Raman-Scattered Light. $\quad J$. Am. Chem. Soc. 133(19), 7288-7291. DOI:10.1021/ja200992x. PMID 21510609.

[62] Atzori, L., Iera, A., G. Morabito, G. (2010). The Internet of things: a survey. Computer Networks, 54(15), 2787-2805.

[63] Yusuf Perwej, M. A., AbouGhaly, B., Kerim, \& Hani Ali, M., Harb. (2019). An Extended Review on Internet of Things (IoT) and its Promising Applications. Communications on Applied Electronics (CAE), Foundation of Computer Science FCS, 9(26), 8-22. DOI: $10.512 /$ case2019652812.

[64] Hutchison, C. (1998). The Virtual University and The Culture of Learning. Education Libraries Journal, 41(1), 5-11.

[65] Jones-Delcorde, D. H. (1999). The Information Age: The Instructor-Computer Dilemma. Education Today, 45(2), 32-33.

[66] Joo, J. E. (1999). Cultural Issues of The Internet in Classrooms. British Journal of Educational Technology, 30(3), 245-250.

[67] Kershaw, A. (1996). People, Planning, and Process: The Acceptance of Technological Innovation in Post-Secondary Organization. Educational Technology, 36(1), 44-48.

[68] Bhuvana R., Madhushree L. M. \& Aithal P. S. (2020). Blockchain as a Disruptive Technology in Healthcare and Financial Services - A Review based Analysis on Current Implementations. International Journal of Applied Engineering and Management Letters (IJAEML), 4(1), 142-155. DOI: http://doi.org/10.5281/zenodo.3822463.

[69] Bhuvana R., \& P. S. Aithal (2020). Blockchain based Service: A Case Study on IBM Blockchain Services \& Hyperledger Fabric. International Journal of Case Studies in Business, IT, and Education (IJCSBE), 4(1), 94-102. DOI: http://doi.org/10.5281/zenodo.3822411.

[70] Bhuvana R., \& P. S. Aithal (2020). RBI Distributed Ledger Technology and Blockchain - A Future of Decentralized India. International Journal of Management, Technology, and Social Sciences (IJMTS), 5(1), 227-237. DOI: http://doi.org/10.5281/zenodo.3839780.

$* * * * * * * * *$ 